\title{
Yakutia in Visual Sources of the 18-19th Centuries: A Brief Overview
}

\author{
Lena Borisovna Stepanova
}

The Department of Archaeology and Ethnography of the Institute for Humanities Research and Indigenous Studies of the North, Russian Academy of the Sciences, Siberian branch, Yakutsk, Russia

Corresponding author. E-mail: solo007_79@rambler.ru

\begin{abstract}
The study of visual sources of the 18 - 19th centuries, outside of the dominant discourse of art criticism, it makes us think about the organized nature of the formation of illustrative materials in all areas of scientific disciplines, which went along with the process of forming large centers of historical memory (libraries, archives, museums) in the country. The creative heritage of expedition artists and photographers who took part in the study of the indigenous peoples of Yakutia in the period under study is considered from the standpoint of the intellectual culture of the era, as the result of a huge work carried out by individual enthusiasts, research societies and public institutions of historical memory of Russia. During the development of new Northern territories and the assessment of its colonization capacity, Russian ethnographic science tested the tools of visual methods of research of traditional everyday life, while simultaneously forming a corpus of clothing and visual sources, subsequently replicated in "pictorial albums"1, opening the world community to the population of the Russian Empire.

The first experiments of drawing fixation of traditional culture made during the expeditions of the Russian Academy of Sciences helped to construct the image of the new Russia.

In the 19th century, with the advent of technical capabilities of photography, the advanced scientific community began to form already photographic visual images of the country's population. Today, these meta-archives of digitized historical memory are experiencing a real Renaissance, as anthropological resources on the basis of which many lost elements of the traditional culture of the past are reconstructed. The study of the results of the work of artists and photographers, as part of the Russian intellectual community, who conducted scientific research and searches in various genres of artistic practices is conducted for the first time.
\end{abstract}

Keywords: art practices, intellectual landscape, visual research, north territories

\footnotetext{
${ }^{1}$ Pictorial albums are a series of illustrated albums on the population of the Russian Empire, published both in Russia and abroad, based on the results of research by expeditions and private travelers.
} 


\section{INTRODUCTION}

"Yakut zemlya" became the object of civilizational expansion of the Russian Empire in the 17th century; however, it first became an object of scientific study only in the 18th century, when the state implemented a major project to study the indigenous population and colonial northern territories in order to develop vast spaces and strengthen borders during the first Northern academic expeditions. Due to the fact that the state was not always able to control the process of research carried out by various expeditions, they were based on the first unified scientific programs, which included conducting written observations with obligatory picture fixing. This was included in the duty of expeditions, as well as for civil servants who were traveling around the country, as well as for individual travelers; that is, they should, if possible, collect collection samples illustrating traditional occupations, beliefs and ways of managing, combining with basic responsibilities. Thus, visual studies became an important part of the expeditionary research conducted by Russian ethnographic science back in the 18th century. The state received a visualization of the climate, geographical features, economy and lifestyle, including new empire territories in the north-east of the country. The need to visualize ethnological observations was based on the activity approach of Russian thinkers (V.N. Tatishchev, I.N. Boltin), who tested the concept of a single Russian state opposed to the West [1].

\section{HISTORIOGRAPHY}

In modern studies of visual anthropology, the first experiences of using the conceptual language of artistic practices to record and transmit the results of scientific research by Russian scientists date back to the works of academic expeditions of the 18th century. [2,3]. There was a theoretical turn in the question of studying the visual heritage of Russian science in domestic historiography in the 2010 s due to the introduction of new historical documents into the scientific circulation and the preparation for publication of large publishing projects related to the publication of the manuscript heritage of the first galaxy of scientists of the Russian Academy of Sciences - D.G. Messerschmidt, I.G. Georgi and G.F. Miller. Conclusions of E.A. Vishlenkova on the visual basis of ethnographic knowledge was once again confirmed in the works of scientists of the Scientific Research Institute of the MAE RAS (Kunstkamera) and the Library of the Russian Academy of Sciences devoted to the history of the organization and results of expeditionary surveys in Northern Eurasia [4-8]. Information about the population was important to replenish the "encyclopedia" of life of various peoples, the possibilities of establishing contacts, were essential for understanding the system of their survival [7]. These publications, devoted to the history of the organization and reassessment of the results of the Northern academic expeditions of the first half of the 18th century, including the art of drawing by artists who were part of their personnel, summarize the primacy of visual perception before intellectual activity.

Integrated collecting programs D.G. Messerschmidt (1717), G.F. Miller (1733) and V.N. Tatishchev (1737) aimed at studying Russian history and its artifacts, population and its traditional occupations, which contributed to the targeted collection of monuments and collections for the Kunstkamera, also included items describing the collection of visual materials at the study sites $[5,7,9]$.

Advances in photography in the second half of the 19th century led to the emergence of new techniques specific to this type of art. The technique of full-scale photography has spread since the 1860s. Ethnographic photography of the second half of the 19th century set itself the goal of reliably fixing people's life. Sequential shooting also occurs during this period. At the beginning of the 20 century, the influence of various trends in painting is still felt in the works of photographers, but at the same time, interest in interpreting the forms of the real world arises and the principles of artistic decisions based on the documentary essence of photography are formed. Therefore, there is an opinion on the purposeful formation of the first visual archives by Russian science that has been formed in historical science since the 1870s, and which most researchers in the field of visual anthropology adhere to [10-12]. This is due to the technical capabilities that photography has opened in the field tools of expeditionary research.

The approach based on the fact that the development of new lands and their study required the simultaneous memorialization of the events is justified in modern foreign historiography on intellectual history, historical memory, as well as the history of the first memory institutions (archives, libraries and museums) [13]. The work of D. Beit, who examined the processes of collecting and acquiring photo collections in memory institutes (archives, libraries, museums), should also be noted as an important achievement of human civilization among works related to the conclusions developed in the framework of this study. Among other things, it allowed various social groups to find identity with a common visualized memory [14]. Today, visual research at the intersection with the visual culture of the studied region is one of the most effective methodological approaches in foreign anthropology. Scientists involved in the study of visual ethnographic archives and methods of their analysis tend to ascertain the growing importance of ethnographic research based on digital resources, since they contain the technological tools necessary for the study of society [1517]. The works of G. Kubica and V. Olszewski resonate in Polish historiography with the theme of this study. In an article devoted to the photo collections that captured 
the Jewish everyday life of Poland, G. Kubica drew attention to the fact that the photographs on which the geographical features of the territory and ethnographic plots of the early twentieth century were recorded were used as a body of knowledge during the Second World War, necessary for the Nazis to control the occupied territories of Poland. Based on these data, she summarizes how visual images of the past can become an informative source for the implementation of geopolitical projects [18]. V. Olszewski notes in his study on the production of ethnographic and visual texts written by Polish exiles in Siberia and Kazakhstan that there is no tendency to reevaluate them in modern Polish historiography and, if mentioned, only in the context of the formation of the national identity of the Polish people [19]. Meanwhile, the analysis of graphic images taking into account the geographical environment in Russian science as a cognitive research strategy was adopted by representatives of Russian scientific thought in the 18th century and was implemented in a series of imperial projects aimed at exploring the country and fixing its cultural and historical heritage. The artistic practices recognized in Russian science since the 18th century have become not only an integral part of the study of the peoples of multiconfessional and multi-ethnic Russia, but also have opened up new possibilities for the formation, extraction and analysis of visual sources.

The methodological tools of the research programs of Russian expeditions of the 18th century emphasized the importance attached to the collection of visual anthropological material. Works of fine art created in the era under study can be divided into several groups: everyday subjects, national costume, historical landscape, views of large cities. The focus on the landscape and on the image of a person correlates well with the enlightening nature of historical research, which was built around the concepts of nature and human nature, based on the theory of geographical determinism: different people live in different conditions and therefore have their own unique history [1].

Beginning in 1717, "naturalists" - expeditionary artists began to prepare according to the samples of the works of the Swiss artist and entomologist Maria Sibylla Merian, the author of the famous entomological album "Metamorphoses of Surinamese Insects" [20]. Drawing fixing becomes an example of visualization of the main markers of ethnicity of a population (national costume, ornament, shape, color) and an important and integral part of the Russian field methodological tools.

\section{METHODOLOGY}

The methodological basis of this study is a comprehensive interdisciplinary approach to the study of visual sources in line with the problem field of intellectual culture and visual research [21]. This review explores the transition from the textual and pictorial perception of the studied region, reflected in the epistolary heritage of travelers of the 18th - first half of the 19th centuries, to the visual language of field expeditionary photography, written in the tools of scientific programs of the 2 nd half of the 19th century.

\section{RESULTS AND DISCUSSION}

Illustrations made during expeditions and travels in northeast Asia in the 18th-19th centuries were included in many periodicals, books and atlases of their time. The first images of cities and the indigenous population of northeast Asia of the Russian Empire appeared in the albums "Collection of Russian and Siberian cities" (St. Petersburg, 1769-1771); "Description of all peoples living in the Russian State" by I.G. Georgi (1776-1799); "La Russie, ou moeurs, usages et costumes des habitants de toutes les provinces de cet empire" Breton (with illustrations by M.F. Damam-Demartre and R. Ker Ker Porter 1813), "The Peoples of Russia, or a Description of the Customs, Habits and Costumes of the diverse Nationalities of the Russian Empire" by K. Rehberg (illustrated by E.M. Korneev, 1812-1813), and "Description ethnographique des Peuples de la Russie" G.T. Pauli (1862).

A specific art engraving dedicated to the city of Yakutsk appeared with incisor engravings on copper of the 18th century; they were made with illustrations by I.V. Lursenius, draftsman of the II Kamchatka expedition, "Russia. View of Yakutsk "(1736)," View of Yakutsk from the west bank of the river. Lena" and" View of Yakutsk and Lena "by the engraver Francois Ney (Late 18th century) from a drawing by L.N. Lespinass (1793). Engraving by the master of the Engraving Chamber of the St. Petersburg Academy of Sciences A.G. Rudakov from the picture of I.V. Lursenius entered the 1771 edition dedicated to Russian and Siberian cities, according to drawings by artists of the Second Kamchatka expedition [22]. The works of an unknown artist capturing the images of a man, woman and girl: Yakut in a hunting dress in front; Yakut in a hunting dress from behind; Yakut woman in front; Yakut woman behind; Yakut girl from the face; Yakut girl with a back; Yakuts. View of the river. Lena entered the famous album of I.G. Georgi "Description of all peoples living in the Russian state: their everyday rites, customs, clothes, dwellings, exercises, fun, faiths and other memorials" [23]. Considering that for a long time only members of the II Kamchatka expedition (1733-1743) worked in Yakutia, we can assume that these are the works of I.V. Lursenius or I.Kh. Berkhan. However, the issue of authorship of engravings is still open $[5,6]$.

Expedition I.I. Billings - G.A. Sarychev (1785-1794), organized by the Decree of Catherine II, made a great contribution to the study of the North East Asia in the field of geography and astronomy, including including in the northern regions of modern Yakutia. G.A. Sarychev 
included in the atlas engravings made from drawings by the regular draftsman of the expedition L.A. Voronin: View of the Verkhne-Kolyma jail from the Asashny river (engraver I. Chesky, 1802); View of the Middle Kolyma prison and the Kolyma river, down that. (engraver $\mathrm{K}$. Chesky. 1802); View of the Yakut village on the tract Omekon. Yakuts in a simple and elegant dress (engraver K. Chesky. 1802); Deer Tungus set up their yurt for an overnight stay (engraver I. Chesky, 1802); Deer Tungus. 1802 (engraver of the Klauber group (I. Chesky?), 1802); The Yakut shaman calls on spirits to heal the patient (Sanders engraver (J.?), 1803) [24]. L.A. Voronin made landscape sketches, types of population, everyday scenes, homes, clothes, utensils, weapons and vehicles. He performed a series of drawings of the Chukchi Sea, Kolyma. Settlements and cities in the Sarychev Atlas appear as a series of gray unpretentious buildings, which they successfully beat at the expense of state symbols. However, a deep sense of disappointment from the Siberian "cities" and shines through them. On his fullscale images, the landscape with the image of the natural landscape always acts as a background.

A series of engravings dedicated to the peoples of the Russian Empire and their costumes appeared in the works of the Russian artist E.M. Korneev (1780-1839), a graduate of the St. Petersburg Academy of Arts. The project "removing the looks and costumes of different nations" was implemented by the artist during a three-year trip to Russia in 1802-1804 as part of the expedition G. Sprengporten [3]. The expedition is notable for the fact that it was organized with the aim of a "military-strategic review" of Asian and European Russia in 1809 and was of a secret nature. The expedition began in Yaroslavl on February 25, 1802, then Nizhny Novgorod, Kazan, the border and trade administrative city of Orenburg, the Troitskaya fortress. Further, through Yekaterinburg, the expedition headed for Eastern Siberia: Tobolsk, Obdorsk (Salekhard). The artist's watercolors depicted Petropavlovsk, Semipalatinsk, Ust-Kamenogorsk, Tomsk, Krasnoyarsk, Verkhneudinsk, Irkutsk, Selenginsk, Kyakhta, Yakutsk, Okhotsk ... [25]. The peoples of Yakutia are represented in the following works of the artist: Winter entertainments of the Tungus; Lamuts; Yakuts (1809). Korneyev's works correspond to the program "Instructions on the artistic part" for expeditionary artists (in the 18th -19 th centuries they were called "naturalists") developed by A.I. Olenin, President of the Academy of Arts. The instruction defined the objects of drawing in detail, the artists had to most accurately carry out a wide variety of specific, portrait and everyday sketches. It was especially important to fix those objects that could not be represented in the collections large relief forms, the general view of the landscape, individual species of plants and animals [3].

Color engravings with images of Yakuts, Evenks and Lamuts, subsequently included in Pauli's album "Peoples of Russia". Italian artists completed a series of prints for the 4th volume of Asia, published in Milan in 1818, from a variety of illustrations by Korneev. In this album, the image of Yakutia in the 19th century is presented in the work of the Italian engraver Giuseppe Castellini "View of the city of Yakutsk and Lena Pillars" (from a picture by Charles de Lespinass) made using the aquatint technique. In 1832, the work of E.M. Korneev was published in Paris by Count Karl Rechberg. The album "Picturesque journey through Russia" in total included 30 prints. The selected works included engravings "Winter entertainments of the Tungus" and "Yakuts" representing the peoples of the North [26]. Due to the exceptional quality of Korneev's work, in the $1860 \mathrm{~s}$, when the experiments in publishing illustrated album editions began to be realized in the academic field, his work was included in the Russian version of The Peoples of Russia, prepared for publication by I. Pauli [27]. Thus, a new art genre appeared in the 19th century, based on the culture of peoples. The release of the Pauli album was certainly one of the major events of the second half of the 19th century. In the author's preface, Pauli ascribes all the merits to himself, justifying that there was not a single essay on the full composition of the Russian population from 1812 to 1860 , and the artistic side of the matter, and the collection of ethnographic drawings from the time of Roth (1774), did not advance much [27]. The publication was carried out at the expense of the author, in honor of the millennium of Russia. Pauli's album is noteworthy in that for every nation, it provides information on its history, geographical location, climate, religion, describes the appearance of people, their costumes, lifestyle, activities and a brief psychological portrait. The visual research methods of the 18th - first half of the 19th centuries were dictated by the need to fix the life world of the "primitive" peoples, their culture and way of life; the wide scope and careful selection of objects of visual fixation, prescribed in the programs and instructions of Russian expeditions since the 1860s, after the recognition of photography as a new accurate method of observation and research, subsequently became a fundamental pillar in the study of cultural areas of northeast Asia. The development of new territories and the expansion of the activities of research societies in the second half of the 19th century can be considered interdependent phenomena. The educational mission of research societies in Russia was that they took the initiative to fill the gaps in the vast research field that fell outside the scope of interests of the Russian Academy of Sciences. For the first time, enthusiasts from the most diverse social backgrounds acted as researchers. Photography becomes a way of visualizing the experience of different peoples in various fields of human activity, including the experience of developing unique adaptive mechanisms for the development of space and nature in various climatic conditions. A review of the instructions and programs for collection collecting and ethnographic research of the 19th century is a comparative methodological experience interesting in methodological terms. 
A great incentive for the formation of the first ethnographic collections and the collection of visual materials in the territory of Yakutia was the programs sent by research societies and instructive orders of the administration of the Yakutsk region for presentation at Russian and international exhibitions. Active expeditionary activity of scientific societies was accompanied by the development of special instructions and gathering programs, which played a significant role in organizing ethnographic research and training specialists to participate in them.

The programs were aimed at providing an idea of the culture of the people, their distinctive traditions from the highlighted most vivid objects. The objects, being combined into a single museum collection, most clearly demonstrated the idea that lay at the basis of collecting, while simultaneously illustrating the collector's luck and trained eye, the scope of his interests and preferences. But they all pursued a common goal: to identify the level of ethnographic research in various regions of Russia. It is noteworthy that collecting work for participation in exhibitions began in 1-2 years according to previously developed programs, and was financially provided by interested organizations and individuals, which guaranteed the amount of fees.

Sustainable development and state security is associated not only with the development of natural wealth and its economic development, but also its cultural development. The popularization and organization of various exhibitions in the second half of the 19th century contributed to Russia's first breakthrough into the world museum space. For the first time, the collection of ethnographic collections in the Yakutsk region was initiated by the Society of Lovers of Natural History and Anthropology at Moscow University to organize an Ethnographic exhibition and museum. In 1865, the OLEA committee asked the governor of Eastern Siberia to take part in the construction of the exhibition and museum, promising to provide the necessary instructions [28]. In anticipation of the preparations for the organization of the Ethnographic Exhibition in 1867, the OLEAE distributed a comprehensive program of ethnographic collections throughout Russia, which, among other things, included the collection of photographs and portraits depicting various ethnic types of the population, as well as natural landscapes [28]. The Yakutsk regional administration, having received instructions from Irkutsk, on the full support of this initiative, in turn sent them for execution to the districts. The Yakutsk regional administration required the execution of its instructions from district police officers, even if it concerned the collection of information for the Siberian department of the Geographical Society. Yakut ethnographic collections collected for the AllRussian Ethnographic Exhibition of 1867 at the initiative of its organizers A.P. Bogdanov and V.A. Dashkov was transferred to the Moscow Public and Rumyantsev Museum. After completion of the exhibition, the Dashkov Ethnographic Museum and the Department of Foreign
Literature were created, the collection of which included the collections exhibited there. Some items from the Yakut department of the exhibition were included in some private collections abroad. Subsequently, the Yakut things presented at the Ethnographic Exhibition in Moscow in 1867 were sent to the World Exhibition in Paris (1867) and from there some of them went to the British Museum [29].

The St. Petersburg Society of Naturalists was established in 1868 at the initiative of doctors and scientists. Members of the society were: artist I.M. Pryanishnikov, botanists K.A. Timiryazev, I.P. Borodin, S.M. Rozanov, geologist A.A. Inostrancev, doctors E.S. Botkin, I.M. Sechenov et al. Professor A.N. Beketov, one of the founders of society, identified the dissemination of science among the wider circles of the Russian intelligentsia and the association of Russian scientists (in 1881, took over as president of society) as the main tasks of society. The company organized expeditions to study the northern outskirts of Russia and carried out work to popularize the natural sciences among the population: public lectures, mass excursions around St. Petersburg, "open days" at the university with demonstration of experiments in laboratories, etc. Expeditions organized by the society examined the northern provinces of the country, the White Sea, the Gulf of Finland, Altai Mountains, Kalmyk steppes, etc. [30]. The beginning of the mass movement in Russia to establish local museums in the country and organize the collection of natural science collections for university museums is connected with the name of A.N. Beketova. In the Yakutsk region, thanks to Beketov's appeal to the Yakutsk Regional Statistical Office in 1887, they started collecting collections for the future Yakutsk Regional Museum (now the Sakha State United Northern Peoples History and Culture Museum named after E. Yaroslavsky).

Since the 1870s, travelers began to enrich their trips with a multitude of ethnographic photographs and drawings. The result was a natural increase in visual images illustrating the features of the provincial outskirts of the country. Therefore, today the materials of the second half of the 19 century in the collection of museums, archives and libraries are the most massive. This is due to an increase in the number of expeditions of various expeditions of Russian and foreign scientific societies, as well as large ethnographic museums in Europe, the USA and Russia that have shown interest in the distant northern territories. In the second half of the 19th century, the logical outcome of the initiatives initiated by scientific societies for integrated visual fixation, the traditional everyday life of the peoples studied throughout the country was the design of the genres "ethnographic photography" and "ethnographic drawing", which includes a large complex of works of different types of art, combined by time parameters and belonging to ethnographic science.

Among the scientific societies that have had a great influence on the development of scientific study of the 
north-east of Siberia, including the systematic collection of clothing and illustrative collections, the Imperial Russian Geographical Society and its Siberian department are of undoubted priority. The department was renamed the East Siberian Department of the Russian Imperial Society (VSOIRGO) in 1877. The department for the study of the region organized expeditions, excursions, conducted observations and made extensive use of the resources of the administrative resource. This is proved by the programs sent by society to the Yakutsk region in 1865-1883. With the mediation of the Governor General of Eastern Siberia, collection was organized for the Ethnographic Exhibition of 1867, for the Anthropological Exhibition in 1879, and for the restoration of the VSOIRGO Museum after a fire in 1878. VSOIRGO also, through the governor of Eastern Siberia, distributed a memo to officials whose activities were connected with traveling character in 1877. Among their duties were the implementation of ethnographic observations and the collection of the most interesting objects of the traditional culture of foreigners, accompanied by a picturesque fixation and photographing of the most interesting moments. The memo contained instructions listing the required photofixation objects: 1 . Settlements, various types of dwellings, farm buildings; 2. Clothing; 3. Handicraft production (individual moments of production); 4. Methods of transportation (sledges, carts, etc.); 5. Activities and crafts (fishing - fishermen's dwellings, fishing tackle; hunting - hunter's equipment, hunting huts and tackle); 6. Mowing [28]. Diary entries were supposed to go on behalf of the traveler, contain statistical conclusions and ethnographic notes. Travel notes should be accompanied by a collection of exhibits. Thus, it can be assumed that traveler's notes, which became widespread in the journal periodicals of the late 19 - early 20 centuries, were based on the guidelines and recommendations developed by VSOIRGO. This explains why in the "notes" a significant place is given to detailed ethnographic descriptions.

The first expedition of a complex nature organized by VSOIRGO was the Vilyui expedition (1853-1854) led by R.K. Maak with the financial support of the gold miner S.F. Solovyov. An extensive herbarium was collected (2.3 thousand plants), numerous observations were recorded on the nature and distribution of vegetation; surveys in the field of zoology and ethnography were carried out (Bazyleva, 2008). The collection of ethnographic information was conducted by the expedition along with other main tasks. Subsequently R.K. Maak, who organized large-scale studies of the Yakutsk region through the VSOIRGO, specifically emphasized in his work that he had never set the task of collecting ethnographic objects (his collection consisted of 85 items lost during a fire in the VSOIRGO museum in 1879). According to R.K. Maak, it is almost impossible to demand from naturalists setting off for the special purpose of researching such a distant, vast and almost completely unexplored region, collecting ethnographic and archaeological information [31]. Nevertheless, the expedition managed to collect significant collections that subsequently died in the fire of the Irkutsk Museum in 1879 and give an ethnographic description that has not lost its significance today. According to M.K. Azadovsky, a significant part of the collected satellite R.K. Maak, A. Brylkin, who was actually entrusted with the ethnographic part in recent expeditions, remained unpublished. Maak managed to publish materials of the Vilyui district only in 1883. The book is illustrated by the works of graphic artist A. Shpiler (View of the Vilyui river (near the mouth of Akhtarynda), Shaman's altar, Brown coal deposits on the left bank of Kempendyaya, Yakut-hunter, Yakut summer dwelling, etc. [32, 33].

Very interesting points are contained in the ethnographic data collection program for the Anthropological Exhibition of 1878, where members of the VSOIRGO took part; it lists the following objects of photographic fixation: 1. Pictures from the tracts, mounds and hillforts associated with the name of the hero with a description of the traditions and about the heroic graves; 2. Pictures from the tracts and hillforts associated with the name of the pagan gods; 3. Pictures from amulets worn for health; 4 . Pictures from trees and stones with medical power; 5 . Pictures with inscriptions and sketches on the rocks. In addition, the program involved the collection of photographs of various nationalities and the separate fixing of representatives of various professions horsemen, peddlers, etc. [34]. Similar objects of photographic fixation are contained in the program for the collection of ethnographic objects of the VSOIRGO museum in Irkutsk in 1883 [35]. He set himself the goal of collecting an ethnographic collection that would give a visual representation of the culture of all peoples inhabiting Eastern Siberia.

A regional feature of the Yakut intellectual circles of the second half of the 19 century was the involvement in scientific and expeditionary work, including work in the Yakutsk Regional Museum of political messengers, who largely determined and shaped the intellectual culture of the region. Interestingly, the photo salons in Yakutsk and the post of conservative of the Yakutsk Regional Museum were transferred by tacit agreement with the city authorities among political exiles. Therefore, it was their results of "personal" experiments of visual research that found their expression in the framework of the museum gathering process and were first presented in Russian and international exhibition projects of the turn of the 19th 20th centuries. An important evidence of the emerging regional visual culture of the Yakutsk region was the practice of production with the subsequent distribution of species albums. In 1896, at an exhibition in Nizhny Novgorod, the Yakutsk region first presented an album with photographs, which P.P. Tian-Shansky. According to some information, the city Duma transferred this album to the funds of the Yakutsk Regional Museum in 1912, but unfortunately it has not survived to our time. In addition to presenting the album, the Yakutsk region presented in 
its pavilion a rich exhibition where viewers could get acquainted with the life and everyday culture of the Yakuts: models of their homes, collections of objects illustrating the means of transportation of the Yakuts (riding deer, dogs, horses, oxen), home furnishings and utensils, then hunting, fishing tools, products of the Yakut smiths, jewelry, Yakut toys and games [36]. According to P.V. Vinokurov, the largest number of ethnographic objects was collected for the Nizhny Novgorod (1896) and Paris (1900) exhibitions [37].

\section{Expedition of Zh.N. Marten (1879, 1883-1884)}

Since the end of the 1870 s, the presence of foreign expeditions, which were equipped including and the latest photographic equipment of its time. In 1879, he visited the Yakutsk region as part of an expedition equipped to search for the missing expedition of De Long, a member of the French Geographical Society and the Moscow Society of Natural History Lovers Joseph Marten (18481892). The expedition discovered the remains of members of the De Long expedition, and also collected geological, paleontological, botanical and ethnographic materials, while simultaneously conducting an expeditionary photo diary. The materials he collected were presented in 1882 at an ethnographic exhibition illustrated with photographic views at the Trocadero Ethnographic Museum in Paris [38]. In 1883, through the Transbaikalia, the expedition reached the valley of the river. Spell, then crossed the watershed between Vitim and Olekma and went to Lake Amoudis. In the valley of the Chary River, they discovered granite rocks, collected collections on geology and botany, including rare ethnographic objects, and formed a geognostic collection. Marten also kept notes on the past terrain. In 1884, he undertook a secondary crossing of the Stanovoi Range and access to the Lena to Yakutsk. However, he only managed to travel along the southern ridge from last year's halt. Having then descended along the Amur River and en route to Manchuria along the way, Marten visited Nikolaevsk, Ussuri, Lake Khanka and, finally, Vladivostok, where he boarded a ship and set off for Europe. In 1887, Martin organized the second ethnographic exhibition at the Trocadero Museum, where he presented clothes, animal skins from which clothes were made, household items, objects of worship and beliefs, hunting and fishing tools of the peoples of Eastern Siberia, mineralogical, geological and paleontological collections. The Siberian collections, after the exhibitions were completed, were donated by the researcher to the museums of France: the Museum of Man (the former Ethnographic Museum of Trocadero, Paris) and the Museum of the History of Lyon. The year 1879 in regional history can be considered a significant milestone with which to begin the countdown of the changes that took place in the Yakut society, when local scientific forces first made themselves known in the
all-Russian scientific space. The head of a rhinoceros ${ }^{2}$ found in the Yana River basin by a local researcher N.S. Gorokhov, was represented at the Moscow Anthropological Exhibition, and thanks to this find, his name entered the world of science. Unfortunately, very little material has been preserved from the scientific heritage of this outstanding researcher, the first paleontologist and ethnographer from the Sakha people, an active member of the Imperial Russian Geographical Society. The archives of the researcher died during the fires at the Irkutsk Museum VSOIRGO in 1878 and in his house in Yakutsk in 1881 [39]. In the summer of 1879 N.S. Gorokhov undertook an expedition with the aim of exploring the possible location of the mammoth at the mouth of the Dulgaly river and physicogeographical study of the region. The diary was published in the Izvestia VSOIRGO journal in 1884 and contains a detailed description of the road path, the condition of the road stations (cook), the number of which needs to be increased, as well as critical comments by the author on their sanitary condition [40]. According to Siberian researchers, part of the sent N.S. Gorokhov's visual materials have survived to our time as part of the collection of the book fund of the Irkutsk Regional Museum of Local Lore ("Fisherman on the River Yana", "Deer Hunting", "Fishing Yurt", etc.) [41].

\section{CONCLUSION}

A review of expedition projects by Russian ethnographic science to study the northern outskirts of the country in the 18th-19th centuries indicates the widespread use of visualization as a separate methodological approach. Modern digitalization processes, which opened access to previously closed collections of rare books and prints, as well as the reprint of antique literature, have opened up great opportunities for exploring the unique visual heritage of expeditionary artists and photographers, previously available only to a narrow circle of researchers.

The scientific world of Russia has tested the possibilities of graphic images in the transmission of information, and visibility has become a feature of all scientific research conducted on its territory. The picture of the scientific study and formation of museum-ethnographic gathering in the Yakutsk region in the 19th century illustrates the fundamental importance of "producing ideas" by Russian intellectual circles, revealing the potential of scientific programs for studying the region and museumethnographic gathering programs from the perspective of the country's domestic policy aimed at strengthening its geopolitical potential.

2 Currently, the head of the rhino is kept in the Zoological Museum of the Russian Academy of Sciences. 
As a result of the active contribution of Russian and regional scientific communities, a group of Russian and local intellectuals interested in the scientific study of the region, an interest in museum work and private collecting is formed, as well as conditions are created for the formation of the visual culture of the region. Thanks to the intellectual processes that circulated in Russian society, which received the vector of the "motherland movement" aimed at exploring the potential of human and subsoil resources, a dialogue was established between the center and its most remote provinces. In addition, this aspect became the initial prerequisite for the demand for art practices and the development of photo art in the everyday culture of Russia (the development of the genres of landscape, home and documentary photography, reportage portraiture in salon and amateur photography).

\section{REFERENCES}

[1] D.N. Shanskij, From the history of Russian historical thought, Publishing house of Moscow University, 1983.

[2] E.A. Vishlenkova, Visual anthropology of the Empire, or "not everyone can see the Russian", Publishing house of Higher school of Economics, 2008.

[3] O.G. Verbina, To the history of a new copy of the album by E. M. Korneev "Peoples of Russia", 18121813 years, in: The origins and evolution of the artistic culture of the Turkic peoples: Materials of the international conference. scientific and practical conference dedicated to the 150th anniversary of the birth of Sh.A. Tagirov, Kazan, 2009, pp. 236-241.

[4] A.V. Golovnev, T.S. Kisser, Ethnoparties Empire in the works of P.S. Pallas and I G. Georgi, Ural historical Bulletin 3(48) (2015) 59-69.

[5] T.S. Kisser, Costumes and drawings: visual folk studies of I.G. Gheorgi, Three centuries of Russian Ethnography: pages of history, Series: From the history of Russian Ethnography, Ethnology and anthropology. Issue 1, 2017.

[6] A.V. Golovnev, Ethnography in the Russian academic tradition, Ethnography 1 (2018) 6-39.

[7] M.V. Hartanovich, Principles of collecting ethnographic collections for the Kunstkamera of the Imperial Academy of Sciences: from the Siberian expedition of D.G. Messerschmidt (1719-1727) to the Second Kamchatka expedition (1733-1743), Bulletin of NSU. Series: History, Philology 18(5) (2019) 36-49.
[8] S.V. Bereznitsky, Method of collecting ethnographic materials of the commander of the Anadyr prison Friedrich Planisner $\left(1760^{\text {th }}\right.$ years), Kunstkammer 3(5) (2019) 189-199.

[9] Museological thought in Russia of the XVIII-XX centuries: Collection of documents and materials, Eterna, 2010.

[10] S.A. Morozov, Russian art photography: essays from the history of photography. 1839-1917, Moscow, 1955.

[11] D.O. Tsypkin, From "research photography" to historical and documentary expertise, Proceedings of the joint scientific Council on humanitarian problems and historical and cultural heritage 2010 (2011) 163-183.

[12] G.V. Dluzhnevskaya, Archaeological research in Central Asia and Siberia in 1859-1959 (according to the documents of the Scientific archive of the Institute of the history of material culture of the Russian Academy of Sciences), ElekSis, 2011.

[13] Le Goff Zh. History and memory, Russian political encyclopedia, 2013.

[14] D. Bate, The Memory of Photography, Photographies 3(2) (2010) 243-257.

[15] G. Rose, On the relation between "visual research methods" and contemporary visual culture, Sociological Review 62(1) (2014) 24-46.

[16] S. Pink, H. Horst, J. Postill, L. Hjorth, T. Lewis, J. Tacchi, Digital Ethnography: Principles and Practice, Sage, 2015.

[17] P. Favero, The image in a digital landscape, European Association of Social Anthropologists (2015) 361-362.

[18] G. Kubica, Ethnographic Photography Documenting Jewish Life in Poland - an Outline, Etnografia nowa 8 (2016) 257-321.

[19] V. Olshevsky, Polish ethnographic relations with Siberia and Kazakhstan from the middle of the XIX to the beginning of the XX century in the context of the development of theoretical Ethnology, Bulletin of Tomsk state University. History 49 (2017) 123-127.

[20] N.P. Kopaneva, Watercolors of Maria Sibylla Merian in the St. Petersburg branch of the Archive of the Russian Academy of Sciences: "I wanted to 
present... divine miracle", Available at: http://ranar.spb.ru/rus/vystavki/id/116/.

[21] L.P. Repina, G.P. Myagkov, Intellectual culture and scientific communication, Bulletin Of Udmurt University. History and Philology 3 (2014) 137-142.

[22] Collection of Russian and Siberian cities. Based on drawings by artists of the Second Kamchatka expedition, Engraving chamber of the St. Petersburg Academy of Sciences, 1769-1771.

[23] I.G. Georgi, Description of all the peoples living in the Russian state: their everyday rituals, customs, clothes, dwellings, exercises, amusements, faiths and other memorabilia, 1799.

[24] Atlas of maps and drawings for the trip to the North-Eastern part of Russia and the Islands of the North Pacific ocean of the fleet of captain G. Sarychev, Schnor printing house, 1802.

[25] D.E. Zolotarev, Artist E. M. Korneev in Siberia and the Altai in 1802 years, Available at: http://new.hist.asu.ru/biblio/borod2/69-331.html.

[26] C.Ch. de Comte Rechberg, Voyage picturesque throughout Russia, decorated with 30 engravings collected by Count Carl Rechberg, and engraved by the best artists, with a historical text compiled by G.P. Depping, 1832.

[27] G.T. Pauli, Ethnographic description of the peoples of Russia, 1862.

[28] National archive of the Sakha Republic (Yakutia). F. 26-I. Op. 1. D. 572, Documents on the collection of ethnographic, anthropological items, monographic and historical information for the society of natural science lovers at Moscow University, 1858-1871.

[29] V.F. Miller, Systematic description of the collection of the Dashkovsky ethnographic Museum, 1887.

[30] A.A. Shcherbakova, Andrey Nikolaevich Beketov

- an outstanding Russian botanist and public figure, Publishing house of the USSR Academy of Sciences, 1958.

[31] M.K. Azadovsky, Ways of ethnographic studies of the East Siberian Department of the Russian Geographical society, in: Publication of the East Siberian Department of the
RGO. With the bibliographer app.index of V.L. Petrova-Smagina, 1926.

[32] R.K. Maak, Vilyuysky district of the Yakut region, Printing and chromolithograph A. Transhel, 1886.

[33] R.K. Maak, Vilyuysky district of the Yakut region, Printing and chromolithograph A. Transhel, 1887.

[34] National archive of the Sakha Republic (Yakutia). F. 26-I. Op. 1. D. 643, Program for collecting ethnographic data for an Anthropological exhibition, 1878 .

[35] National archive of the Sakha Republic (Yakutia). F. 26-I. Op. 1. D. 748, The program for the collection of ethnographic objects of the Museum of the VSORGO in Irkutsk, 1883.

[36] V.H. Ivanov, Yakut bone carving, Nauka, 1979.

[37] P.V. Vinokurov, Full and interesting (Yakutia at the Nizhny Novgorod exhibition of 1896 year), Yakut archive 1 (2000) 55-62.

[38] Zh.D. Berzhe, Joseph Martin's last journey, Available at:

https://www.fergananews.com/town/martine.html.

[39] P.L. Kazaryan, Nikita Semyonovich Gorokhov: life, deeds, scientific heritage, NEFU publishing house, 2012.

[40] N.S. Gorohov, Diary of a journey from Verkhoyansk to the upper reaches of the Dulgalakh river and back, made in the summer of 1879 - the Old highway from Verkhoyansk to Yakutsk, Izvestiya VSOIRGO 14(4-5) (1884) 1-20.

[41] L.M. Kolesnik, A.S. Kovaleva, Artists and photographers in the Siberian Department of the Russian geographical society, Local history notes 11 (2004) 4-13. 